\title{
GEOCHEMISTRY OF THE GAS MANIFESTATIONS OF GREECE: METHANE AND LIGHT HYDROCARBONS
}

\section{Daskalopoulou K. ${ }^{1}$, D’Alessandro W. ${ }^{2}$, Cabassi J. ${ }^{3}$, Calabrese S. ${ }^{1}$, Fiebig J. ${ }^{4}$, Grassa F. ${ }^{2}$, Kyriakopoulos K. ${ }^{5}$, Parello F. ${ }^{1}$ and Tassi F. ${ }^{3}$}

\author{
${ }^{1}$ Università degli Studi di Palermo, Dipartimento della Terra e del Mare, via Archirafi, 36, 90123, \\ Palermo,Italy, kyriaki.daskalopoulou@unipa.it,sergio.calabrese@gmail.it, \\ francesco.parello@unipa.it \\ ${ }^{2}$ Istituto Nazionale di Geofisica e Vulcanologia, via Ugo la Malfa 153, 90146, Palermo, Italy, \\ walter.dalessandro@ingv.it, fausto.grassa@ingv.it \\ ${ }^{3}$ Università degli Studi di Firenze, Dipartimento della Terra, via G. La Pira 4, 50121, Florence, \\ Italy, jacopo.cabassi@unifi.it, franco.tassi@unifi.it \\ ${ }^{4}$ Goethe-Universität, Institut für Geowissenschaften, Altenhöferallee 1, 60438 Frankfurt am Main, \\ Germany, Jens.Fiebig@em.uni-frankfurt.de \\ ${ }^{5}$ National and Kapodistrian University of Athens, Department of Geology and Geoenvironment, \\ Panepistimioupolis, Ano Ilissia, 15784, Athens, Greece, ckiriako@geo.uoa.gr
}

\begin{abstract}
Greece has a very complex geodynamic setting deriving from a long and complicated geological history being characterized by intense seismic activity and enhanced geothermal gradient. This activity, with the contribution of an active volcanic arc, favours the existence of many gas manifestations. Depending on the prevailing gas species, the latter can be subdivided in three main groups: $\mathrm{CO}_{2^{-}}, \mathrm{N}_{2^{-}}$and $\mathrm{CH}_{4-}$ dominated. In the present work, we focus on methane and light hydrocarbons $\left(\mathrm{C}_{2}-\mathrm{C}_{6}\right)$ to define their origin. $\mathrm{CH}_{4}$ concentrations ( $<2$ to $\left.915,200 \mu \mathrm{mol} / \mathrm{mol}\right)$ and isotopic ratios $\left(\delta^{13} C-79.8\right.$ to $+16.9 \%$, $\delta D-298$ to $+264 \%$ ) cover a wide range of values indicating different origins and/or secondary post-genetic processes. Samples from gas discharged along the Ionian coast and in northern Aegean Sea have a prevailing microbial origin. Cold and thermal gas manifestations of central and northern Greece display a prevalent thermogenic origin. Methane in gases released along the active volcanic arc is prevailingly abiogenic, although thermogenic contributions cannot be excluded. Gases collected in the geothermal areas of Sperchios basin and northern Euboea are likely affected by strong secondary oxidation processes, as suggested by their highly positive $C$ and $H$ isotopic values (up to $+16.9 \%$ and $+264 \%$ respectively) and low $C_{1} /\left(C_{2+} C_{3}\right)$ ratios.
\end{abstract}

Keywords: Hellenic territory, hydrothermal gases, cold gas emissions, origin of hydrocarbon gases.

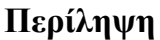

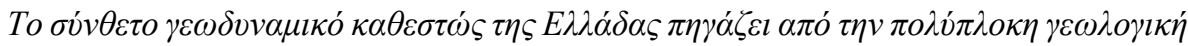

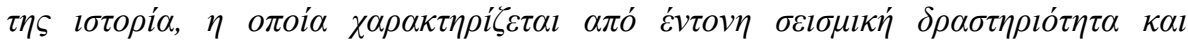

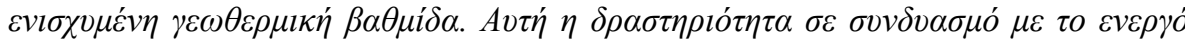




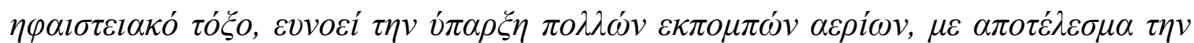

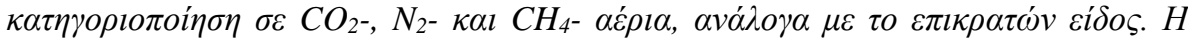

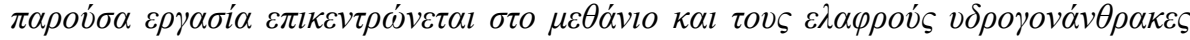

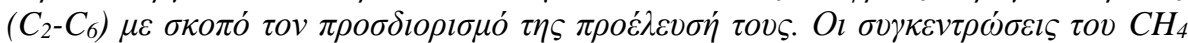

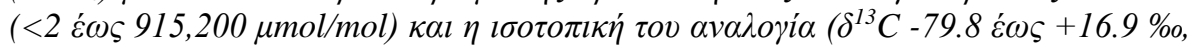

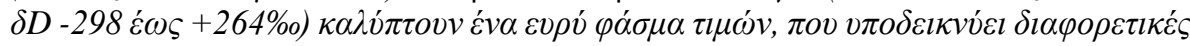

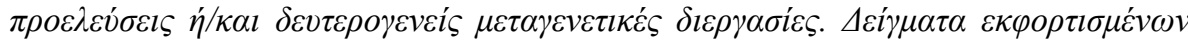

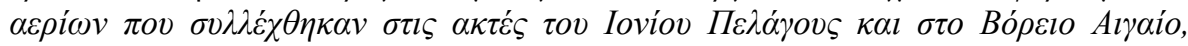

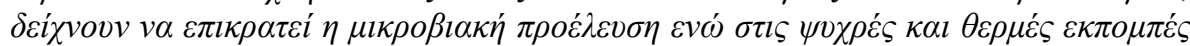

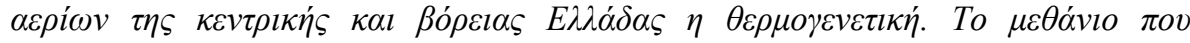

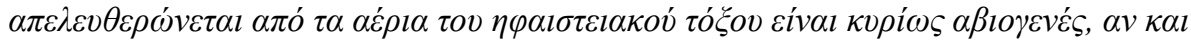

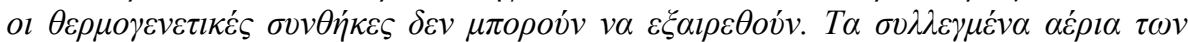

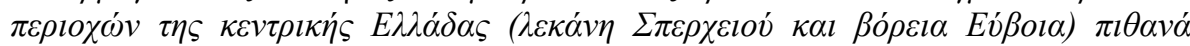

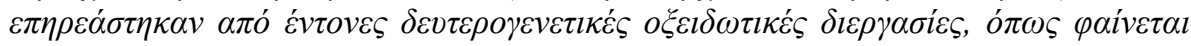

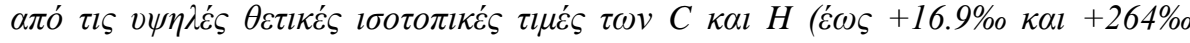

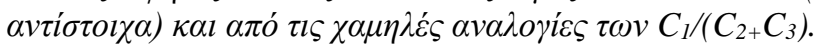

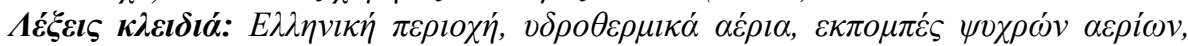
$\pi \rho о \varepsilon ́ \lambda \varepsilon v \sigma \eta v \delta \rho o \gamma o v \alpha \nu \theta \rho \alpha ́ \kappa \omega \nu$.

\section{Introduction}

The Hellenic territory has a complex geodynamic setting deriving from a long and complicated geological history. Due to this specific geological background, conditions for the formation of many thermal springs were favoured (D'Alessandro et al., 2006, 2008, 2010, 2011; Kyriakopoulos et al., 2010). The major geodynamic activity in macroscale gave rise to a geological evolution which is expressed in volcanism, orogenetic processes and active tectonics. Widespread volcanic activity in the Aegean Sea started in the Oligocene and continues to the present. Two major phases took place. The first one was developed in the North Aegean area from the Oligocene to the Middle Miocene and the second started in the Pliocene forming the active South Aegean Volcanic Arc. During the Oligocene - Miocene volcanic phase the volcanic activity occurred in an East to West oriented zone from Thrace to the Central Aegean. Many places of the Aegean region (North Euboea, Tinos, Sikinos, Patmos and Samos Islands) were affected by this activity. Chemical- physical conditions related to the recent volcanism, coupled with the major faults were the fundamental causes for the warming and uplift of deep thermal waters, resulting in this discharge at the surface thermal springs (Fytikas et al., 1984; Pe-Piper et al., 1989).

Geochemical studies based on the isotopic composition of carbon and hydrogen, along with helium isotopic ratios have become a good indicator of the origin of the gas. The isotopic ratio ${ }^{13} \mathrm{C} /{ }^{12} \mathrm{C}$ of $\mathrm{CO}_{2}$ expressed in $\delta{ }^{13} \mathrm{C}(\%)$, may provide important information about the amount of $\mathrm{CO}_{2}$ released from the Earth's crust or mantle. Carbon and hydrogen isotopic compositions and $\mathrm{C}_{1} /\left(\mathrm{C}_{2}+\mathrm{C}_{3}\right)$ hydrocarbon ratios can characterize the origin of methane. In sedimentary environments, $\mathrm{CH}_{4}$ is primarily produced by 1) processes related to metabolic and biosynthetic activity of biological organisms (biogenesis), and 2) decomposition of organic matter buried in sediments at $\mathrm{T}>150{ }^{\circ} \mathrm{C}$ (thermogenesis) (Schoell, 1980, 1988; Whiticar et al., 1986; Galimov, 1988; Welhan, 1988; Whiticar and Suess, 1990; Whiticar, 1999). Helium isotopic ratios provide additional information about crustal or mantle origin of the gas.

This study is focusing on methane and light hydrocarbons and is having as an aim the identification and the characterization of methane's origin and the identification of post-genetic processes affecting hydrocarbon gases. 


\section{Geodynamic setting and volcanism of Greece}

The Hellenides are the result of the collision of several microcontinental fragments with the margin of Eurasia through the Cretaceous and Paleogene (van Hinsbergen et al., 2005). After the collision, the Hellenides have been characterized by widespread extension, particularly since the Miocene, as a result of subduction rollback from the oceanic crust of the African plate. The modern fault pattern is a result of the westward and southwestward motion of the Aegean-Anatolian microplate with respect to the Eurasian plate.

The Paleogene Hellenide orogeny of Greece and its eastward continuation into western Turkey resulted from the collision of the Apulian microcontinental fragment in the Eocene to Oligocene with the Pelagonian, Rhodope, and Serbo-Macedonian fragments, which had previously accreted to the southern margin of Eurasia in the Cretaceous. Subsequent extension in the Aegean was rapid, likely due to subduction rollback over residual oceanic crust of the African plate, whereas Anatolia had been bounded by African continental crust south of Cyprus since the Early Miocene. This regional extension and the thermal effects of asthenospheric upwelling, related to changes in the geometry of subducting slabs, have been interpreted as causing magma genesis principally within the lithospheric mantle (Pe- Piper and Piper, 2002).
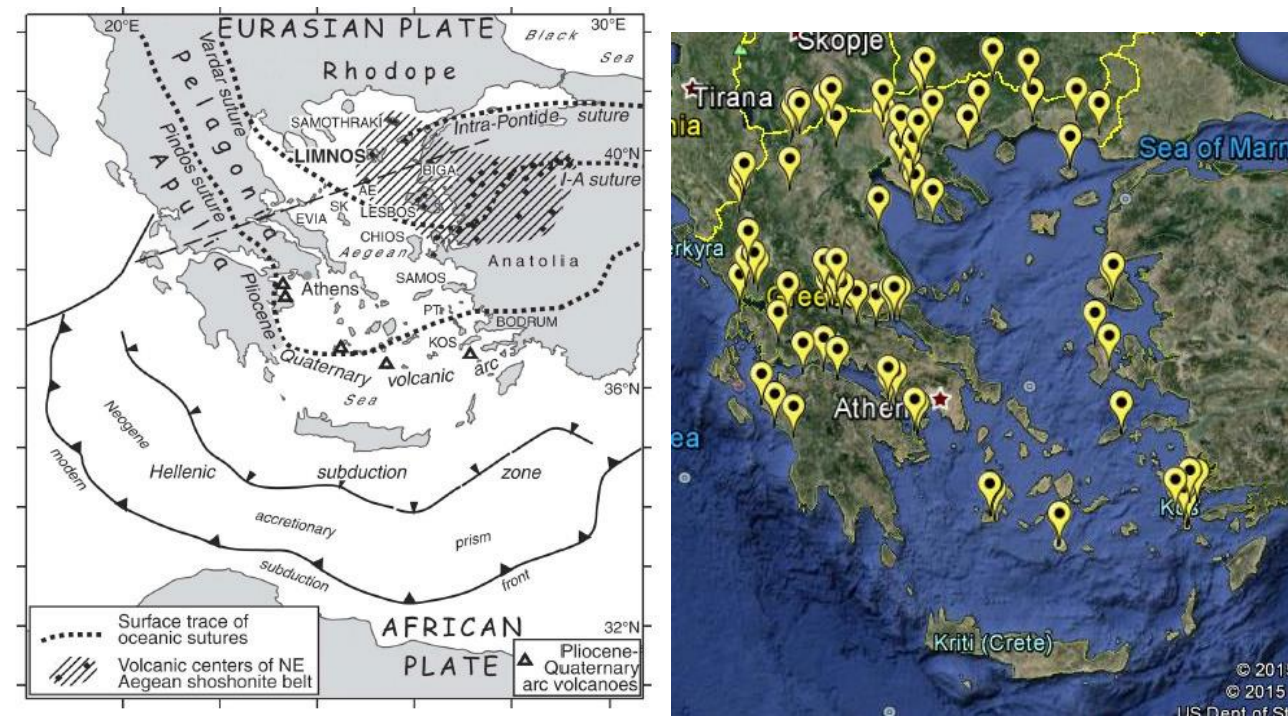

Figure 1 - a) Map that shows the plate boundaries and the geodynamic pattern of Greece and the Ionian and Aegean Seas (Pe-Piper, 2006). This map was the criteria used for the categorization of the samples collected in the Hellenic territory as seen in Figure b.

At the south Aegean Volcanic Arc the activity started during the Upper Pliocene (Fytikas et al., 1986) and is currently active at solfataric stage. The calc-alkaline volcanic activity of Southern Aegean region developed in various volcanic centers from Sousaki to Nisyros through MethanaPoros, Milos and Santorini. The volcanic products are dominated by lava domes and lava flows with associated minor pyroclastic breccias and felsic ignimbritic covers (Mitropoulos et al., 1987). The final activity of this orogenic cycle is characterized by the presence of K-rich shoshonites and latites with ultrapotassic character.

On the basis of the previous description of the Hellenic geodynamic setting, the whole territory has been subdivided into 5 homogeneous areas (see map of fig. 1a): Apulia, Pelagonia, Rhodope, North Aegean and South Aegean active volcanic arc. The results of the present study will be discussed in the light of such subdivision. 


\section{Fluid emissions in Greece}

Greece, like many other Mediterranean countries (e.g. Italy and Turkey) has a significant geothermal potential, since most areas of the country are geodynamically active as a result of the movement of the African plate towards the Eurasian plate. Heat flow higher than $80 \mathrm{~m} / \mathrm{Wm}^{2}$ characterize several regions, mainly in the internal Hellenides and the Aegean Sea. Such an intense volcanotectonic activity caused the geological conditions for accumulation of heat energy, as testified by the occurrence of low-medium and high enthalpy hydrothermal systems. The most important highenthalpy geothermal fields are located in the Southern Aegean, along the active volcanic arc (Milos, Nisyros), whereas medium and low enthalpy reservoirs are mostly associated with grabens (Central Aegean) and post-orogenic sedimentary molassic basins (southern boundaries of the Rhodope and Servo-Macedonian Massifs) (Fytikas et al., 2005).

\section{Materials and Methods}

Bubbling gases were sampled using an inverted funnel positioned above the bubbles, whereas soil gases were collected by inserting a pipe in the soil and driving the gas by a syringe and a 3-way valve. Gases were collected in $12 \mathrm{ml}$ Exetainer ${ }^{\circledR}$ vials (only for hydrocarbons) and glass sampling bottles equipped with two vacuum stopcocks.

In the laboratory, samples were analyses for $\mathrm{He}, \mathrm{H}_{2}, \mathrm{O}_{2}, \mathrm{~N}_{2}, \mathrm{CH}_{4}$ and $\mathrm{CO}_{2}$ by gas-chromatography (Perkin Elmer Clarus500 equipped with a double Carboxen 1000 columns, TCD-FID detectors) using argon as the carrier gas. Analytical uncertainties were $\pm 5 \%$. Hydrocarbon analysis, were performed with a Shimadzu 14a gas-chromatograph equipped with a Flame Ionization Detector (FID) using helium as the carrier gas. The analytical error was $\leq 5 \%$. The ${ }^{13} \mathrm{C} /{ }^{12} \mathrm{C}$ ratios of $\mathrm{CO}_{2}$ (expressed as $\delta^{13} \mathrm{C}-\mathrm{CO}_{2} \%$ V-PDB) were measured with a Finnigan Delta $\mathrm{S}$ mass spectrometer after purification of the gas mixture by standard procedures using cryogenic traps (precisions $\pm 0.1 \%$ ). Carbon and hydrogen isotopic compositions of $\mathrm{CH}_{4}$ were measured using a Thermo TRACE GC and a Thermo GC/C III interfaced to a Delta Plus XP gas source mass spectrometer. ${ }^{13} \mathrm{C} /{ }^{12} \mathrm{C}$ ratios are reported here as $\delta{ }^{13} \mathrm{C}$ values $( \pm 0.2 \%$ ) with respect to the V-PDB standard. H/D ratios are reported here as $\delta \mathrm{D}$ values $( \pm 2 \%$ ) with respect to the $\mathrm{V}$-SMOW standard.

\section{Results and discussion}

The gas samples collected in the Hellenic territory (Fig 1b) display a large variability in the chemical composition. Helium ranges from 0.10 to $3372 \mathrm{ppm}$ and shows a fair positive correlation with $\mathrm{N}_{2}$. Almost 112 samples out of 399 have detectable $\mathrm{H}_{2}(>2 \mathrm{ppm})$ concentrations ranging from 3.50 up to $149,100 \mathrm{ppm} . \mathrm{O}_{2}$ concentrations range from below the detection limit (<200 ppm - 45 samples) up to 192,700. The concentrations of $\mathrm{N}_{2}, \mathrm{CH}_{4}$ and $\mathrm{CO}_{2}$ range from 600 up to 995,100 ppm, from less than 2 up to $915,200 \mathrm{ppm}$ and from less than 50 up to $999,900 \mathrm{ppm}$. The last three species represent always the main gas component and all the samples can be subdivided in $\mathrm{N}_{2^{-}}, \mathrm{CH}_{4^{-}}$or $\mathrm{CO}_{2}$ - dominated gases.

The $\mathrm{O}_{2}-\mathrm{N}_{2}-\mathrm{CO}_{2}$ triangular graph (Fig. 2a) reveals that only few samples plot close to the point representing atmospheric air excluding important contaminations for most of the samples. The majority of the gases display $\mathrm{N}_{2} / \mathrm{O}_{2}$ ratios less than air or Air Saturated Waters (ASW), which is indicating that the atmospheric component of meteoric water has been modified by redox reactions that took place either in the subsoil or in the aquifers. Furthermore, most of the samples show a strong contribution of helium deriving either from a crustal or mantle sources.

As shown by the $\mathrm{CH}_{4}-\mathrm{N}_{2}-\mathrm{CO}_{2}$ triangular plot (Fig $2 \mathrm{~b}$ ), only few samples, mostly from Apulia, display a $\mathrm{CH}_{4}$ - dominated composition. In general, the collected samples can also be subdivided in 3 groups: 
a) $\quad \mathrm{CO}_{2}$ - dominated, consisted of the samples collected in the Volcanic Arc and a part of Pelagonia and Aegean,

b) $\quad \mathrm{N}_{2}$ - dominated, consisted of a part of the samples collected in Pelagonia and Rhodope

c) $\mathrm{CH}_{4}$ - dominated, consisted of the samples mainly collected in Apulia (Fig 2a, 2b).

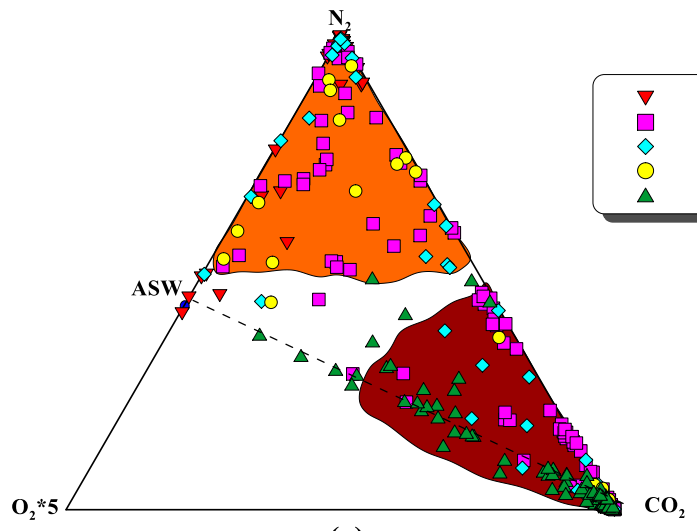

(a)

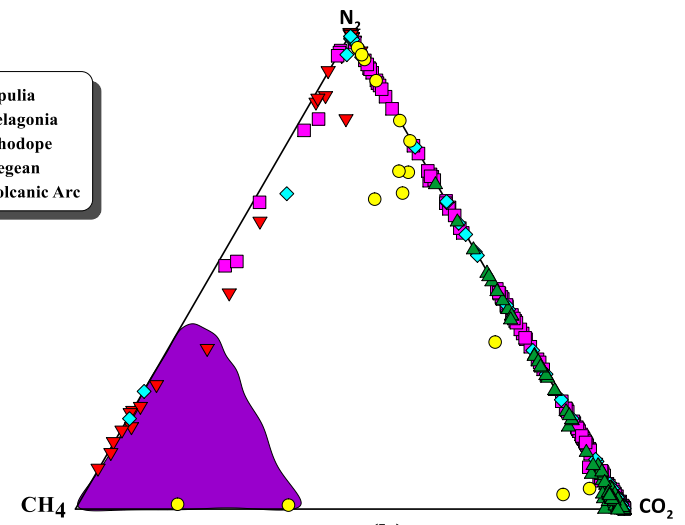

(b)

Figure 2 - Ternary plots of a) $\mathrm{O}_{2}-\mathrm{N}_{2}-\mathrm{CO}_{2}$, b) $\mathrm{CH}_{4}-\mathrm{N}_{2}-\mathrm{CO}_{2}$ in which are plotted the samples divided by geographic areas. The polygons represent the dominant gas: $\mathrm{CO}_{2}-$ dominated, red, $\mathrm{N}_{2}$ - dominated, orange, $\mathrm{CH}_{4}$ - dominated, purple.

He isotopic values, expressed as ${ }^{3} \mathrm{He} /{ }^{4} \mathrm{He}$ ratio, normalized to the atmospheric one $\left(\mathrm{Ra}=1.386 * 10^{-6}\right)$, range from 0.03 to $6.70 \mathrm{R} / \mathrm{Ra}$. Measured values corrected for the atmospheric contamination of the sample on the base of its ${ }^{4} \mathrm{He} /{ }^{20} \mathrm{Ne}$ ratio (Sano and Wakita, 1985) display a similar range (Rc/Ra $0.02-6.73)$. Such a wide range is indicative of different sources for He in the studied gases.
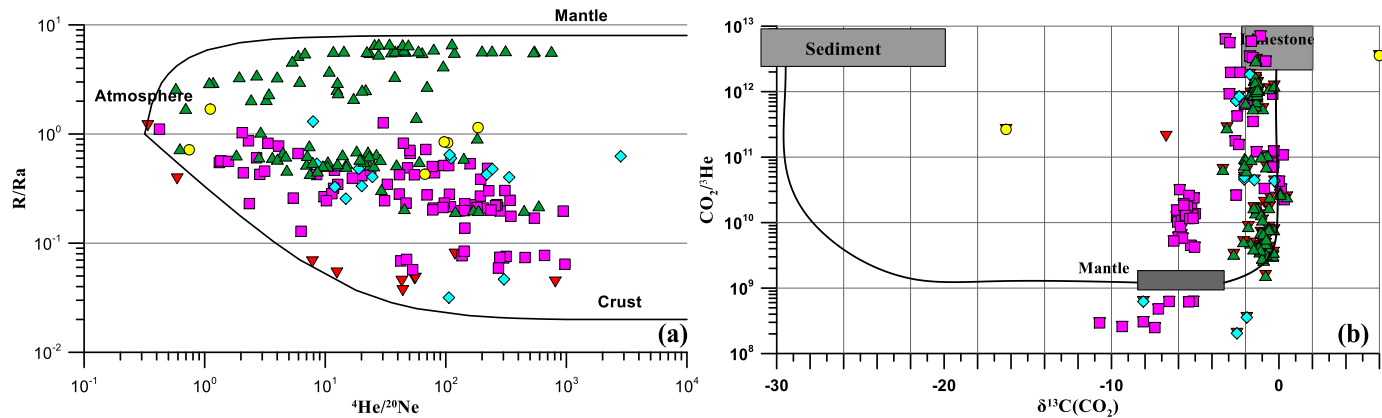

Figure 3 - a) Binary plot of $\mathrm{R} / \mathrm{Ra}$ vs. ${ }^{4} \mathrm{He} /{ }^{20} \mathrm{Ne}$ of the natural gas manifestations of Greece.

Atmosphere, Mantle and Crust represent three possible end-members: atmospheric air,

MORB-like mantle and crust. The mixing lines between Atmosphere and Mantle and between Atmosphere and Crust are also plotted, b) Binary plot of $\mathrm{CO}_{2} /{ }^{3} \mathrm{He}$ vs. $\delta^{13} \mathrm{C}\left(\mathrm{CO}_{2}\right)$ of natural gas manifestations of Greece. The end-member compositions for Sediments, MORB-

like Mantle and Limestones are $\delta^{13} \mathrm{C}\left(\mathrm{CO}_{2}\right)=-30 \%$, $-5 \%$ and $0 \%$ and $\mathrm{CO}_{2}{ }^{\beta} \mathrm{He}=1 * 10^{13}$, $2 * 10^{9}$ and $1 * 10^{13}$, respectively (Sano and Marty, 1995).

On Fig. 3a, the measured values of $\mathrm{R} / \mathrm{Ra}$ are plotted against the ${ }^{4} \mathrm{He} /{ }^{20} \mathrm{Ne}$ ratio. Only few samples plot close to the atmospheric end member, confirming that the atmospheric contribution is negligible. The majority of the samples collected in the Volcanic Arc display high contributions of mantle component, as shown by the highest Rc/Ra ratios (up to 6.73) found at the islands of Kos and Nisyros. Samples collected in Apulia show a prevailingly crustal component with $\mathrm{Rc} / \mathrm{Ra}$ ratios $<0.1$. The 
remaining samples (Pelagonia, Rhodope, Aegean) show a mixed mantle-crustal composition with $\mathrm{Rc} / \mathrm{Ra}$ ratios up to 2.15 .

The carbon isotopic composition of $\mathrm{CO}_{2}$ of the free gas samples displays a wide range from - 16.5 to $+6.0 \%$ (vs. V-PDB) although the majority falls in a narrower range (from -6.0 to $+0.0 \delta^{13} \mathrm{C}\left(\mathrm{CO}_{2}\right)$ $\%$ ). By taking into account the $\delta^{13} \mathrm{C}\left(\mathrm{CO}_{2}\right)$ values and the $\mathrm{CO}_{2} /{ }^{3} \mathrm{He}$ ratios (Fig. 3b), it is noticed that the majority of the collected samples is a mixture of mantle and limestone end-members, whereas the contribution of the sedimentary organic member to the fluids deriving from the descending slab is considered to be insignificant. However, a small contribution from organic sediments can be detected in the $\mathrm{CO}_{2}$ - dominated gases of Apulia deriving from crustal sources. On the contrary, $\mathrm{CH}_{4}$ and $\mathrm{N}_{2}$ - dominated gases display sometimes a strong organic contribution and low $\mathrm{CO}_{2} /{ }^{\beta} \mathrm{He}$ ratios (samples collected in Pelagonia and Rhodope) probably due to $\mathrm{CO}_{2}$ - depleting processes $\left(\mathrm{CO}_{2}\right.$ dissolution in groundwater, carbonate precipitation, $\mathrm{CO}_{2}$ reduction, etc.).

Thermogenic $\mathrm{CH} 4$ has been reported to exhibit $813 \mathrm{C}(\mathrm{CH} 4)$ values ranging from -50 up to $-30 \% \mathrm{~V}$ PDB, whereas microbial CH4 usually has $\delta 13 \mathrm{C}(\mathrm{CH} 4)$ values $<-50 \%$ V-PDB (e.g., Whiticar, 1999; McCollom and Seewald, 2007). However, these limit values may vary depending on processes occurring during gas migration, such as isotopic fractionation by diffusion (Prinzhofer and Battani, 2003), secondary methanogenesis and anaerobic biodegradation (Dimitrakopoulos and Muehlenbachs, 1987; Pallasser, 2000; Etiope et al., 2009). Gases produced by the decay of organic matter at $\mathrm{T}>150{ }^{\circ} \mathrm{C}$ (thermogenic gases) are commonly characterized by $\mathrm{CH} 4 /(\mathrm{C} 2 \mathrm{H} 6+\mathrm{C} 3 \mathrm{H} 8)$ concentration ratios (the so called "Bernard parameter") $<100$, whereas higher ratios $(>1000)$ are expected when hydrocarbon production derives exclusively from microbial activity (Whiticar and Suess, 1990; Jenden et al., 1993). As previously pointed out, concentrations of CH4 as well as its isotopic composition cover a wide range ( $<2$ to $915.200 \mu \mathrm{mol} / \mathrm{mol}$ and $\delta 13 \mathrm{C}$ from $-79.8 \%$ to +16.9 $\%$, $\delta \mathrm{D}$ from $-298 \%$ to $+264 \%$ respectively) indicating different origins and/or secondary post genetic processes. On Fig. 4a and 4b, it is shown that samples from gas discharge located in Apulia and North Aegean likely have a microbial origin, as suggested by the low $\delta 13 \mathrm{C}(\mathrm{CH} 4)$ values (down to $-79.8 \%$ for Apulia and down to $-45.9 \%$ for Aegean) and high $\mathrm{C} 1 /(\mathrm{C} 2+\mathrm{C} 3)$ ratios (highest values reaching up to 9000). The cold and thermal manifestations of Rhodope and a part of Apulia and Pelagonia seem to display a thermogenic origin. CH4 released along the Volcanic Arc, seems to be prevailingly abiogenic (Fiebig et al., 2009; Tassi et al., 2012, 2012) according to the high $\delta 13 \mathrm{C}(\mathrm{CH} 4)$ values $(>-25 \%)$ and high $\mathrm{C} 1 /(\mathrm{C} 2+\mathrm{C} 3)$ ratios (up to 16,000$)$, although thermogenic contribution cannot be excluded. Some of the remaining gases of Apulia and Pelagonia are affected by secondary oxidation processes, as highlighted by their high isotopic values of $\mathrm{H}$ and $\mathrm{C}$ (up to $+16.9 \%$ and $+264 \%$ respectively) and their low $\mathrm{C} 1 /(\mathrm{C} 2+\mathrm{C} 3)$ ratios. Incubation experiments on waters and sediments of some of these springs, showed that the oxidation of $\mathrm{CH} 4$ is generally microbially driven.

As shown in Fig. 5, the $\mathrm{CH} 4 / \mathrm{C} 2 \mathrm{H} 6$ concentration ratios of the studied gases vary by more than three orders of magnitude, whereas the ratios between the light hydrocarbons (C2H6, C3H8 and C6H6) vary by less than two orders of magnitude. As far as this evidence is concerned, the redox processes between $\mathrm{CO} 2(\mathrm{CO})$ and $\mathrm{CH} 4$, which likely controls the $\mathrm{CH} 4$ abundance in volcanic-hydrothermal fluids, does not affect the higher alkanes whose origin could be entirely related to thermal degradation of organic matter. At the same time, the residual methane seems to retain its primary carbon isotopic composition due to the possible low degree of polymerization. This could also explain why there is no significant correlation between the carbon isotopic composition of methane and the $\mathrm{CH} 4 /(\mathrm{C} 2 \mathrm{H} 6+\mathrm{C} 3 \mathrm{H} 8)$ values for gases from volcanic environments (Fig. 5a and $5 \mathrm{~b}$ ), whose $\delta 13 \mathrm{C}(\mathrm{CH} 4)$ seems to be controlled by $\delta 13 \mathrm{C}(\mathrm{CO} 2)$ and temperature. In addition, methane polymerization may explain why volcanic-hydrothermal gas emissions exhibit a spread to much lower $\mathrm{CH} 4 /(\mathrm{C} 2 \mathrm{H} 6+\mathrm{C} 3 \mathrm{H} 8)$ concentration ratios than the geothermal discharges. 

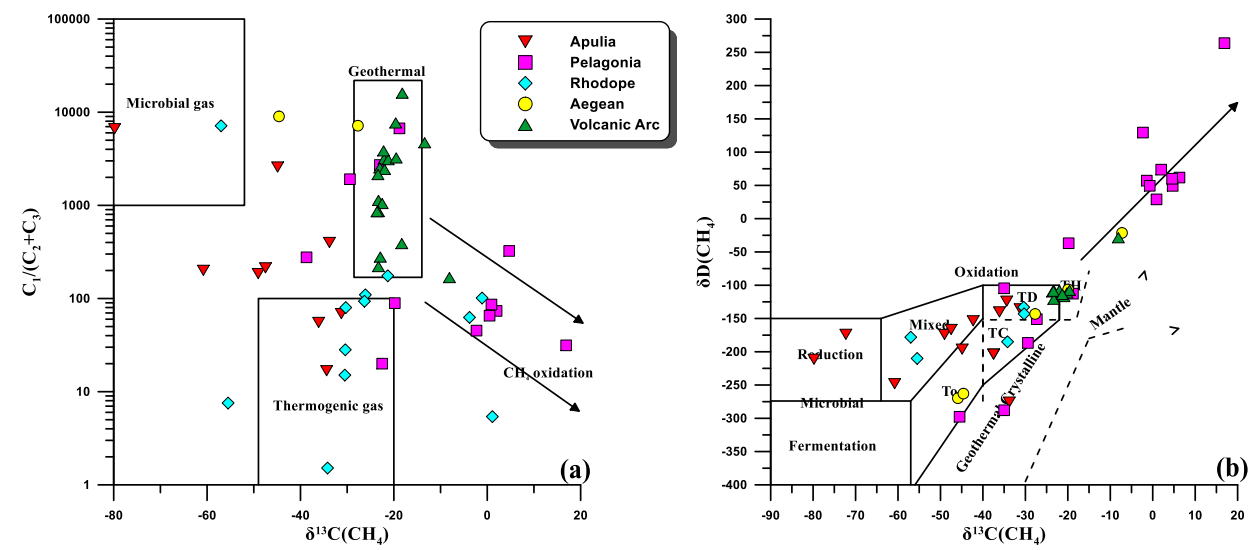

Figure 4 - a) $\mathrm{C}_{1} /\left(\mathrm{C}_{2}+\mathrm{C}_{3}\right)$ vs $\delta^{13} \mathrm{C}\left(\mathrm{CH}_{4}\right)$ and b) $\delta \mathrm{D}\left(\mathrm{CH}_{4}\right)$ vs $\delta^{13} \mathrm{C}\left(\mathrm{CH}_{4}\right)$ diagrams for the Hellenic gas discharges.

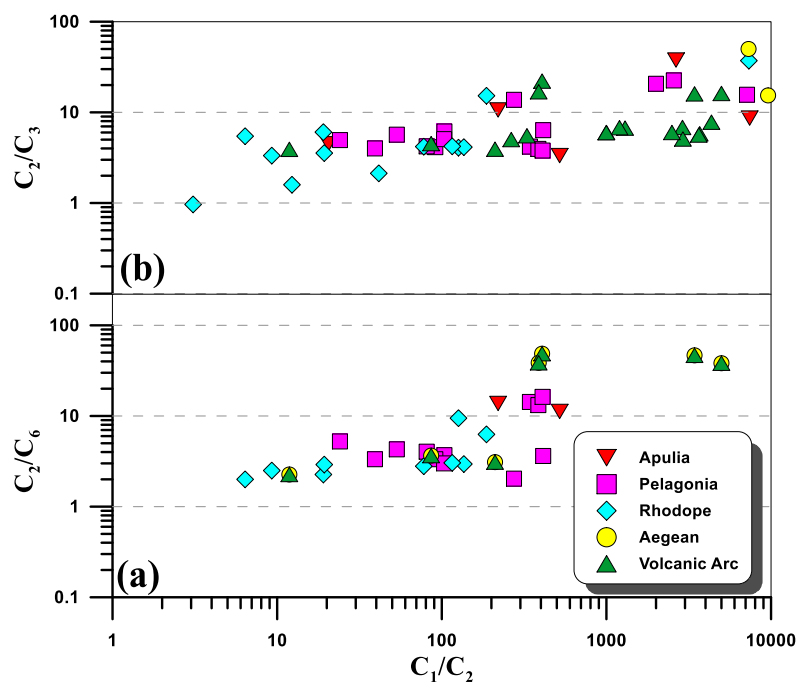

Figure 5 - a) $\mathrm{CH}_{4} / \mathrm{C}_{2} \mathrm{H}_{6}$ vs. $\mathrm{C}_{2} \mathrm{H}_{6} / \mathrm{C}_{3} \mathrm{H}_{8}$ and b) $\mathrm{CH}_{4} / \mathrm{C}_{2} \mathrm{H}_{6}$ vs. $\mathrm{C}_{2} \mathrm{H}_{6} / \mathrm{C}_{6} \mathrm{H}_{6}$ binary plots for the Greek gas discharges.

\section{Conclusions}

The chemical and isotopic compositions of $\mathrm{CH}_{4}$ indicate that this gas has different primary sources and is significantly affected by secondary post-generic processes (oxidation). The preliminary results of this study show that the Hellenic territory can be subdivided in 4 groups according to the gas compounds dominating the chemical composition of gas emissions (Fig. 6) as follows:

a) along the Volcanic arc, gases are $\mathrm{CO}_{2}$-dominated, with $\mathrm{CH}_{4}$ showing a hydrothermal origin (abiotic and / or thermogenic) and a prevailing mantle component for $\mathrm{He}$ and $\mathrm{CO}_{2}$.

b) the Apulia region shows $\mathrm{N}_{2}-\mathrm{CH}_{4}$ - dominated gases with a biogenic origin for $\mathrm{CH}_{4}$ and a dominant crustal component for He.

c) Pelagonia, Rhodope and Aegean regions show variable composition $\left(\mathrm{CO}_{2}, \mathrm{CH}_{4}\right.$ and $\mathrm{N}_{2^{-}}$ dominated) with a mixed crustal component for $\mathrm{He}$, whereas $\mathrm{CH}_{4}$ is mainly thermogenic. 
d) in the Sperchios Basin and northern Evia area (Pelagonia), the $\mathrm{CH}_{4}$ is strongly affected by oxidation processes probably microbial driven.

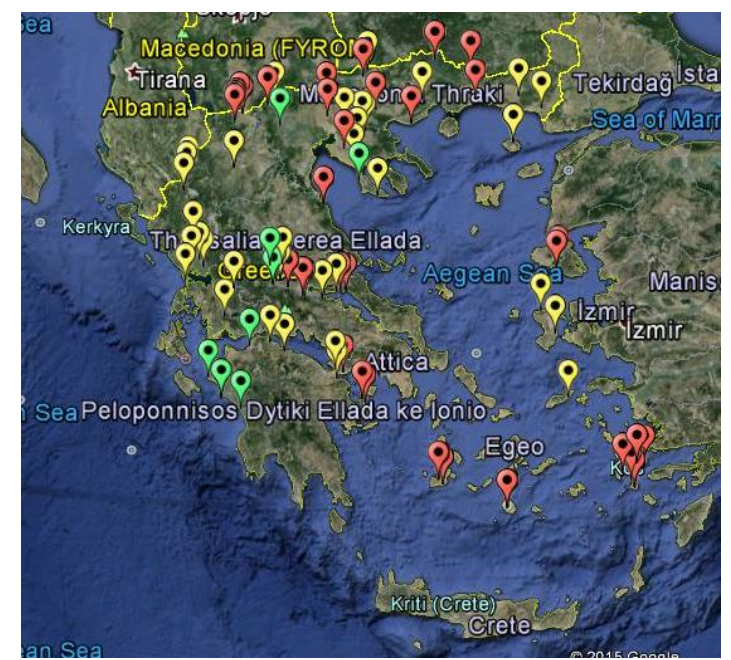

Figure 6 - Map of the Hellenic territory with the dominated gases in the sampled regions, with red color are shown the $\mathrm{CO} 2$ dominated sampling points, with yellow the $\mathrm{N} 2$ and with green the CH4.

\section{References}

Andritsos, N., Dalampakis, P., Karydakis, G., Kolios, N. and Fytikas, M., 2007. Update and characteristics of low-enthalpy geothermal applications in Greece, Proceedings, European Geothermal Congress EGC 2007, May 30 - June 1, 2007, Unterhaching, Germany.

D’Alessandro, W., Brusca, L., Kyriakopoulos, K., Rotolo, S., Michas, G., Minio, M. and Papadakis, G., 2006. Diffuse and focussed carbon dioxide and methane emissions from the Sousaki geothermal system, Greece, Geophys. Res. Lett., 33, L05307, doi: 10.1029/2006GL025777.

D’Alessandro, W., Brusca, L., Kyriakopoulos, K., Michas, G. and Papadakis, G., 2008. Methana, the westernmost active volcanic system of the south Aegean arc (Greece): insight from fluids geochemistry, J. Volcanol. Geotherm. Res., 178, 818-828.

D'Alessandro, W., Bellomo, S., Brusca, L., Fiebig, J., Longo, M., Martelli, M., Pecoraino, G. and Salerno, F., 2009. Hydrothermal methane fluxes from the soil at Pantelleria Island (Italy), $J$. Volcanol. Geotherm. Res., 187, 147-157.

D'Alessandro, W., Brusca, L., Martelli, M., Rizzo, A. and Kyriakopoulos, K., 2010. Geochemical characterization of natural gas manifestations in Greece, Proceedings of the 12th International Congress of the Geological Society of Greece, Patras, May 2010, Bulletin of the Geological Society of Greece, 43(5), 2327-2337.

D’Alessandro, W., Bellomo, S., Brusca, L., Karakazanis, S., Kyriakopoulos, K. and Liotta, M., 2011. The impact on water quality of the high carbon dioxide contents of the groundwater in the area of Florina (N. Greece). In: Lambrakis, N., Stournaras, G. and Katsanou, K., eds., Advances in the research of aquatic environment, Springer, Berlin, 2, 135-143.

D'Alessandro, W., Brusca, L., Kyriakopoulos, K., Bellomo, S. and Calabrese, S., 2014. A geochemical traverse along the "Sperchios Basin - Evoikos Gulf" graben (Central Greece): Origin and evolution of the emitted fluids, Marine and Petroleum Geology, 55, 295-308, doi: 10.1016/j.marpetgeo.2013.12.011.

Dimitrakopoulos, R. and Muehlenbachs, K., 1987. Biodegradation of petroleum as a source of 13C enriched carbon dioxide in the formation of carbonate cements, Chemical Geology, 65, 283-291. 
Etiope, G., Feyzullayev, A., Milkov, A.V., Waseda, A., Mizobe, K. and Sun, C.H., 2009. Evidence of subsurface anaerobic biodegradation of hydrocarbons and potential secondary methanogenesis in terrestrial mud volcanoes, Marine and Petroleum Geology, 26, 1692-1703.

Evans, W.C., White, L.D. and Rapp, J.B., 1998, Geochemistry of some gases in hydrothermal fluids from the southern Juan de Fuca ridge, Journal of Geophysical Research, 15, 305-313.

Fiebig, J., Chiodini, G., Caliro, S., Rizzo, A., Spandenberg, J. and Hunziker, J.C., 2004. Chemical and isotopic equilibrium between $\mathrm{CO} 2$ and $\mathrm{CH} 4$ in fumarolic gas discharges: generation of $\mathrm{CH} 4$ in arc magmatic-hydrothermal systems, Geochimica et Cosmochimica Acta, 68, 2321-2334.

Fiebig, J., Woodland, AB., D'Alessandro, W. and Puttmann, W., 2009. Excess methane in hydrothermal emissions is abiogenic, Geology, 37(6), 495-8.

Fytikas, M., Innocenti, F., Manetti, P., Mazzuoli, R., Peccerillo, A. and Villari, L., 1984. Tertiary to Quarternary evolution of volcanism in the Aegean region, Geological Society of London, Special Publications, 17, 687-699.

Fytikas, M., Innocenti, F., Kolios, N., Manetti, P. and Mazzuoli, R., 1986. The Plio- Quaternary volcanism of the Saronikos area (western part of the active Aegean volcanic arc), Annales Geologique des Pays Helleniques, 33, 23-45.

Fytikas, M., Andritsos, N., Dalabakis, P. and Kolios, N., 2005. Greek Geothermal Update 20002004, Proceedings of the World Geothermal Congress-2005, 24-29 April 2005, AntalyaTurkey (invited paper).

Galimov, E.M., 1988. Sources and mechanisms of formation of gaseous hydrocarbons in sedimentary rocks, Chemical Geology, 71, 77-95.

Jenden, P.D., Hilton, D.R., Kaplan, I.R. and Craig, H., 1993. Abiogenic hydrocarbons and mantle helium in oil and gas fields. In: Howell, D.G., ed., The Future of Energy Gases: US Geological Survey Professional Paper, 1570, 31-56.

Kyriakopoulos, K, 2010. Natural degassing of carbon dioxide and hydrogen sulphide and its environmental impact at Milos island, Greece. In: Proceedings of 12th international congress, Patras, May 2010, Bull Geol Soc Greece.

McCollom, T.M. and Seewald, J.S., 2007. Abiotic synthesis of organic compounds in deep sea hydrothermal environments, Chemical Reviews, 107, 382-401.

Mitropoulos, P., Tarney, J., Saunders, D. and Marsh, N., 1987. Petrogenesis of Cenozoic volcanic rocks from the Aegean Island Arc, Journ. Volcanology and Geothermal Research, 32, 177-193.

Pallasser, R.J., 2000. Recognising biodegradation in gas/oil accumulations through the $\delta 13 \mathrm{C}$ compositions of gas components, Organic Geochemistry, 31, 1363-1373.

Pe-Piper, G. and Piper, D.J.W., 2006. Unique features of the Cenozoic igneous rocks of Greece. In: Dilek, Y. and Pavlides, S., eds., Postcollisional tectonics and magmatism in the Mediterranean region and Asia, Geological Society of America, Special Paper, 409, 259-282.

Prinzhofer, A.A. and Battani, A., 2003. Gas isotopes tracing: an important tool for hydrocarbon exploration, Oil and Gas Science and Technology, 58(2), 229-311.

Sano, Y. and Marty, B., 1995. Origin of carbon in fumarolic gas from island arcs, Chemical Geology, 119, 265-274.

Sano, Y. and Wakita, H., 1985. Geographical distribution of 3He/4He in Japan: implications for arc tectonics and incipient magmatism, Journal of Geophysical Research, 90, 8729-8741.

Schoell, M., 1980. The hydrogen and carbon isotopic composition of methane from natural gases of various origins, Geochimica et Cosmochimica Acta, 44, 649-661.

Schoell, M., 1988. Multiple origins of methane in the Earth, Chemical Geology, 71, 1-10.

Tassi, F., Fiebig, J., Vaselli, O. and Nocentini, M., 2012. Origins of methane discharging from volcanic-hydrothermal, geothermal and cold emissions in Italy, Chem. Geol., 310-311, 3648. http://dx.doi.org/10.1016/j.chemgeo.2012.03.018.

Tassi, F., Bonini, M., Montegrossi, G., Capecchiacci, F., Capaccioni, B. and Vaselli, O., 2012. Origin of light hydrocarbons in gases from mud volcanoes and $\mathrm{CH} 4$-rich emissions, Chem. Geol., 294-295, 113-126. 
van Hinsbergen, D.J.J., Langereis, C.G. and Meulenkamp, J.E., 2005. Revision of the timing, magnitude and distribution of Neogene rotations in the western Aegean region, Tectonophysics, 396, 1-34, doi: 10.1016/j.tecto.2004.10.001.

Vaselli, O., Tassi, F., Montegrossi, G., Capaccioni, B. and Giannini, L., 2006. Sampling and analysis of volcanic gases, Acta Volcanol., 18, 65-76.

Whiticar, M.J., Faber, E. and Schoell, M., 1986. Biogenic methane formation in marine and freshwater environments: $\mathrm{CO} 2$ reduction vs. acetate fermentation - isotopic evidence, Geochimica et Cosmochimica Acta, 50, 693-709.

Whiticar, M.J. and Suess, E., 1990. Hydrothermal hydrocarbon gases in the sediments of the KingGeorge Basin, Bransfield Strait, Antarctica, Applied Geochemistry, 5, 135-147.

Whiticar, M.J., 1999. Carbon and hydrogen isotope systematics of bacterial formation and oxidation of methane, Chemical Geology, 161, 291-314.

Welhan, J.A., 1988. Origins of methane in hydrothermal systems, Chemical Geology, 71, 183-198.

Zhang, J., Quay, P.D. and Wilbur, D.O., 1995. Carbon isotope fractionation during gas-water exchange and dissolution of CO2, Geochimica et Cosmochimica Acta, 59, 107-114. 